\title{
Spinocerebellar Ataxia Type 12
}

National Cancer Institute

\section{Source}

National Cancer Institute. Spinocerebellar Ataxia Type 12. NCI Thesaurus. Code

C154316.

An autosomal dominant sub-type of spinocerebellar ataxia caused by mutation(s) in the PPP2R2B gene, encoding serine/threonine-protein phosphatase $2 \mathrm{~A} 55 \mathrm{kDa}$ regulatory subunit $B$ beta isoform. It presents with characteristic action tremors in the upper limbs, followed by other movement abnormalities. 